\title{
Organogênese de explante foliar de clones de Eucalyptus grandis x E. urophylla
}

\author{
Elisa Cristina Soares de Carvalho Alves ${ }^{(1)}$, Aloísio Xavier ${ }^{(2)}$ e Wagner Campos Otoni ${ }^{(1)}$
}

\begin{abstract}
(1)BIOAGRO - Instituto de Biotecnologia Aplicada à Agropecuária, CEP 36571-000 Viçosa, MG. E-mail: soarescarvalho@hotmail.com, wotoni@ufv.br (2)Universidade Federal de Viçosa, Dep. de Engenharia Florestal, CEP 36571-000 Viçosa, MG. E-mail: xavier@ufv.br
\end{abstract}

Resumo - O objetivo deste trabalho foi avaliar os efeitos dos reguladores de crescimento TDZ [1-fenil-3-(1,2,3-tiadiazol-5-il)uréia], BAP (6-benzilaminopurina) e ANA (ácido naftalenoacético) no desempenho da propagação in vitro por organogênese de explante foliar de três clones híbridos de Eucalyptus grandis x Eucalyptus urophylla. Houve resposta diferenciada dos clones quanto a intensidade, textura e coloração dos calos, em razão dos tratamentos com os reguladores de crescimento. Os melhores resultados de calejamento dos três genótipos foram observados nos tratamentos com a combinação dos reguladores de crescimento TDZ $\left(0,5 \mathrm{mg} \mathrm{L}^{-1}\right)$ e ANA $\left(0,1 \mathrm{mg} \mathrm{L}^{-1}\right)$, obtendo-se $100 \%$ de calejamento no explante foliar. Os piores resultados de calejamento foram observados nos tratamentos com a combinação dos reguladores de crescimento $\operatorname{BAP}\left(0,1 \mathrm{mg} \mathrm{L}^{-1}\right)$ e $\operatorname{ANA}\left(0,1 \mathrm{mg} \mathrm{L}^{-1}\right)$. Em relação à regeneração, a melhor resposta foi obtida com $1,0 \mathrm{mg} \mathrm{L}^{-1} \mathrm{BAP}$ em que $8 \%$ dos calos formados a partir de explantes foliares regeneraram gemas, com número médio destas formadas por calo igual a 4,2.

Termos para indexação: micropropagação, reguladores de crescimento, propagação in vitro.

\section{Organogenesis of the leaf explant of Eucalyptus grandis $x$ E. urophylla clones}

\begin{abstract}
The aim of this work was to evaluate the effects of growth regulators TDZ [1-phenil-3-(1,2,3-thiadiazol-5-yl) urea], BAP (6-benzilaminopurine) e NAA (Naphthalene acetic acid) on the in vitro propagation by organogenesis from foliar explants of Eucalyptus grandis x E. urophylla. Depending on the clone used, there were singular responses to growth regulators treatment regarding callusing intensity, texture and color. The best results of the three genotypes used were observed with the TDZ $\left(0.5 \mathrm{mg} \mathrm{L}^{-1}\right)$ and NAA $\left(0.1 \mathrm{mg} \mathrm{L}^{-1}\right)$ treatment, where $100 \%$ of the foliar explants presented callus. The worst results were observed with the BAP $\left(0.1 \mathrm{mg} \mathrm{L}^{-1}\right)$ and NAA $\left(0.1 \mathrm{mg} \mathrm{L}^{-1}\right)$ treatment. Subsequently, considering the regeneration process, the best response was achieved with $1.0 \mathrm{mg} \mathrm{L}^{-1} \mathrm{BAP}$, in which $8 \%$ of the calli regenerated buds, with an average of 4.2 buds per explant.
\end{abstract}

Index terms: micropropagation, growth regulators, in vitro propagation

\section{Introdução}

Os eventos organogênicos ocorrem mediante a desdiferenciação e rediferenciação celular, dependendo da retomada da atividade meristemática em células maduras diferenciadas ou em um tecido calogênico desorganizado. O processo de organogênese in vitro é complexo, com atuação de múltiplos fatores externos e internos envolvendo interação entre fonte de explante, meio de cultura e fatores do ambiente (George, 1993; Pierik, 1997; Joy IV \& Thorpe, 1999). O processo de organogênese depende, também, da ação de reguladores de crescimento exógenos, em particular auxinas e citocininas, e da habilidade do tecido em responder a essas mudanças hormonais durante o período de cultivo (Sugiyama, 1999).
Na maioria dos trabalhos realizados visando à propagação in vitro de Eucalyptus via organogênese, utilizaram-se materiais juvenis como fonte de explantes, tais como hipocótilos (Kitahara \& Caldas, 1975; Tibok et al., 1995; Azmi et al., 1997; Ho et al., 1998), cotilédones (Azmi et al., 1997), caule e folhas de material juvenil proveniente de sementes (Subbaiah \& Minocha, 1990; Chen et al., 1996; Mullins et al., 1997) e embriões zigóticos (Serrano et al., 1996). Contudo, a possibilidade e otimização de protocolos eficientes de micropropagação de clones superiores poderia constituir-se em alternativa no processo de multiplicação vegetativa, além de atender a programas de transformação genética.

Entre os trabalhos realizados com Eucalyptus, nos quais foram utilizados como fontes de explantes materi- 
ais em idade adulta, o de Lainé \& David (1994) constou de estudos de organogênese in vitro com explantes foliares de clones micropropagados de Eucalyptus grandis. Estes autores constataram a existência de diferenças no requerimento com relação aos reguladores de crescimento, para organogênese, entre os diferentes clones. Hervé et al. (2001) desenvolveram estudos com clones de Eucalyptus gunnii e utilizaram como explantes folhas e segmentos internodais e nodais.

Na propagação in vitro de Eucalyptus, a grande variação genotípica em resposta aos meios de cultura constitui importante fator. No entanto, os reguladores de crescimento constituem a primeira etapa a ser abordada, quando o modo de interação entre auxinas e citocininas é freqüentemente dependente da espécie da planta e do tipo de tecido utilizado na cultura (Coenen \& Lomax, 1997; Pierik, 1997). A maneira complexa com que os reguladores de crescimento e as células interagem indica que, se o tecido não está em um estádio responsivo, este não irá responder adequadamente aos reguladores de crescimento exógenos, não importando em quais concentrações e combinações esses reguladores são utilizados. Ausência na resposta a um regulador de crescimento é freqüentemente um problema maior quando explantes de plantas adultas são utilizados, em comparação com material juvenil (Bonga \& Von Aderkas, 1992).

Diante da escassez de informações referentes à organogênese in vitro em tecidos adultos de Eucalyptus, faz-se necessária a adequação de protocolos de regeneração utilizando explantes coletados de clones selecionados, em que a utilização de material rejuvenescido in vitro possibilitaria melhor performance na capacidade organogênica dos explantes.

Desta forma, métodos eficientes para regeneração de clones selecionados pela via organogênica, utilizando como explante de material rejuvenescido, poderiam constituir-se em alternativa de multiplicação vegetativa, além de atender a programas de transformação genética.

O objetivo deste trabalho foi avaliar os efeitos dos reguladores de crescimento TDZ, BAP e ANA no desempenho da propagação in vitro por organogênese de explante foliar de três clones híbridos de Eucalyptus grandis $\mathrm{x}$ E. urophylla.

\section{Material e Métodos}

Foram utilizados três clones híbridos de Eucalyptus grandis provenientes das empresas V\&M Florestal Ltda. (clone 1, híbrido de Eucalyptus grandis $\mathrm{x}$ E. urophylla) e Celulose Nipo-Brasileira S.A. - Cenibra (clones 2 e 3, híbridos de Eucalyptus grandis $\mathrm{x}$ E. urophylla), os quais foram inicialmente propagados vegetativamente por estaquia, introduzidos em laboratório de cultura de tecidos pela técnica de micropropagação por meio de gemas axilares. A seguir, passaram por sucessivos subcultivos na fase de multiplicação, para seu rejuvenescimento. Os clones 1,2 e 3 encontravam-se em banco clonal no $25^{\circ}$, $19^{\circ}$ e e $22^{\circ}$ subcultivos, respectivamente, quando foi iniciado este trabalho.

O meio de cultura utilizado na multiplicação do material foi composto pelos sais básicos de MS (Murashige \& Skoog, 1962), vitaminas de White (1943), acrescidos de mio-inositol (100 mg L $\left.\mathrm{m}^{-1}\right)$, PVP (800 $\left.\mathrm{mg} \mathrm{L}^{-1}\right)$, sacarose (3\%), ágar granulado $(0,5 \%), 0,3 \mathrm{mg} \mathrm{L}^{-1}$ de BAP (6-benzilaminopurina) e $0,01 \mathrm{mg} \mathrm{L}^{-1}$ de ANA (ácido naftalenoacético), com pH ajustado para 5,8.

Este trabalho foi composto de duas etapas: a primeira referente à produção de gemas alongadas in vitro para obtenção dos explantes foliares, e a segunda, para obtenção dos calos e regeneração das gemas adventícias.

Na obtenção do explante foliar, foi utilizada a técnica de micropropagação mediante proliferação de gemas axilares, conforme referido, modificando-se apenas a concentração dos reguladores de crescimento para $0,1 \mathrm{mg} \mathrm{L}^{-1}$ de ANA e $0,05 \mathrm{mg} \mathrm{L}^{-1}$ de BAP, a fim de promover o alongamento das brotações em banco clonal. Os explantes foliares foram retirados da parte superior (até o 3 o nó) das brotações alongadas, conservando-se parte do pecíolo.

A micropropagação por organogênese foi composta pelas fases de indução de calo e da regeneração das gemas, utilizando o meio de cultura LD conforme Lainé \& David (1994). O meio de cultura utilizado na fase de indução de calo foi composto pelos sais: $\mathrm{KNO}_{3}$ (750 mg L $\left.\mathrm{m}^{-1}\right), \mathrm{NH}_{4} \mathrm{H}_{2} \mathrm{PO}_{4}\left(250 \mathrm{mg} \mathrm{L}^{-1}\right), \mathrm{MgSO}_{4} .7 \mathrm{H}_{2} \mathrm{O}$ (250 mg L $\mathrm{m}^{-1}$ ) e $\mathrm{CaCl}_{2} \cdot 2 \mathrm{H}_{2} \mathrm{O}$ (106 mg L-1); micronutrientes e FeEDTA na metade da concentração de MS, mio-inositol (100 mg L $\left.{ }^{-1}\right)$, sacarose (2\%), vitaminas compostas por ácido nicotínico $\left(10 \mathrm{mg} \mathrm{L}^{-1}\right)$, tiamina. $\mathrm{HCl}$ $\left(10 \mathrm{mg} \mathrm{L}^{-1}\right)$, pantotenato de cálcio $\left(1 \mathrm{mg} \mathrm{L}^{-1}\right)$, piridoxina. $\mathrm{HCl}\left(1 \mathrm{mg} \mathrm{L}^{-1}\right)$, biotina $\left(0,01 \mathrm{mg} \mathrm{L}^{-1}\right)$, MES (600 mg L-1), caseína hidrolisada (250 $\left.\mathrm{mg} \mathrm{L}^{-1}\right)$, PVP (800 $\mathrm{mg} \mathrm{L}^{-1}$ ) e Phytagel $(0,25 \%)$, com $\mathrm{pH}$ ajustado para 5,7. Na fase de regeneração de gemas, utilizou-se o mesmo meio de cultura, alterando o $\mathrm{Fe}$ e micronutrientes para suas concentrações totais, de acordo com o meio MS. Na minimização das contaminações por bactérias, acrescentaram-se aos meios de cultura $300 \mathrm{mg} \mathrm{L}^{-1}$ do antibiótico timentim, após autoclavagem. 
Quanto à avaliação dos tipos e concentrações de reguladores de crescimento na organogênese dos três clones de Eucalyptus, foram utilizados, na fase de indução de calos, combinações de TDZ [1-fenil-3-(1,2,3-tiadiazol-5-il)uréia] e ANA (ácido naftalenoacético), respectivamente, em mg L ${ }^{-1}(\mathrm{~T} 1: 0,5+0,5 ; \mathrm{T} 2: 0,5+0,1$; T3: $0,05+0,01$; T4: $1,0+0,1$ ); e das combinações de BAP (6-benzilaminopurina) com ANA (ácido naftalenoacético), respectivamente, em $\mathrm{mg} \mathrm{L}^{-1}$ (T5: $0,1+0,1$; T6: $0,5+0,5 ; \mathrm{T} 7: 1,0+3,0 ; \mathrm{T} 8: 1,0+1,0)$. Na fase de regeneração de gemas, foram utilizadas combinações de BAP e ANA, respectivamente, em mg L-1 (T1: $0,2+0,2 ; \mathrm{T} 2: 0,3+0,0 ; \mathrm{T} 3: 0,5+0,2 ; \mathrm{T} 4: 1,0+0,0$; T5: $1,0+3,0 ; \mathrm{T} 6: 3,0+0,0 ; \mathrm{T} 7: 0,1+0,05)$.

Os explantes foliares foram colocados nos meios de indução de calos, em placas de Petri descartáveis estéreis $(60 \times 15 \mathrm{~mm})$. Cada placa continha $12 \mathrm{~mL}$ de meio de cultura e cinco explantes, constituindo assim uma unidade experimental. Cada tratamento foi constituído por 10 repetições, e o delineamento experimental utilizado foi o inteiramente casualizado.

$\mathrm{Na}$ fase de indução de calos, as placas foram mantidas em regime de escuridão à temperatura de $27 \pm 2^{\circ} \mathrm{C}$ por cinco semanas. A seguir foi realizada uma avaliação quanto à intensidade de calejamento e aspecto geral do calo (textura e coloração). O critério adotado na avaliação da intensidade de calejamento foi: 1 , pouco calejamento, 2, calejamento médio e 3, calejamento intenso.

A textura - coesão entre as células que formam o calo - foi avaliada em friável (células frouxamente ligadas), compacta (células firmemente ligadas) e texturas intermediárias, classificadas como semifriável e semicompacta.

Em relação às colorações avaliadas na fase de indução de calos, foram classificadas como branco, branco com bege, bege-claro e bege-escuro. O begeescuro refere-se a calos de coloração mais escura, mas que não estão oxidados.

$\mathrm{Na}$ regeneração de gemas, novos calos foram obtidos mediante explantes foliares de cada clone proveniente do melhor tratamento da fase anterior. Eles foram cultivados em novo meio de cultura em placas de Petri descartáveis estéreis $(60 \times 15 \mathrm{~mm})$, contendo $12 \mathrm{~mL}$ de meio de cultura com cinco calos por placa, constituindose assim uma unidade experimental. Cada tratamento foi constituído por 10 repetições, e o delineamento experimental foi o inteiramente casualizado, conforme referido anteriormente. Os tratamentos foram mantidos a $27 \pm 2^{\circ} \mathrm{C}$, sob fotoperíodo de 16 horas de luz e 8 horas de escuro por 35 dias. A densidade luminosa foi de
$36 \mu \mathrm{mol} \mathrm{m} \mathrm{m}^{-2} \mathrm{~s}^{-1}$, obtida de lâmpada luz do dia branca fluorescente de $20 \mathrm{~W}$.

A avaliação da capacidade organogênica do material de cada tratamento com calos provenientes de explantes foliares foi tomada em porcentagem de calos apresentando gemas regeneradas e número de brotações por calo, como também mudanças ocorridas no aspecto desses calos após a transferência para a condição de luminosidade.

As gemas regeneradas foram transferidas para meio de alongamento composto pelos sais básicos MS, vitaminas White, acrescidos de mio-inositol $\left(100 \mathrm{mg} \mathrm{L}^{-1}\right)$, PVP (800 $\left.\mathrm{mg} \mathrm{L}^{-1}\right)$, sacarose (3\%), ágar granulado (0,5\%), 0,05 mg L-1 de BAP e 0,1 mg L-1 de ANA, com $\mathrm{pH}$ ajustado para 5,8 .

No enraizamento das brotações, foi utilizado o meio composto pelos sais básicos MS, vitaminas de White, acrescidos de mio-inositol (100 mg L-1), PVP $\left(800 \mathrm{mg} \mathrm{L}^{-1}\right)$, sacarose (3\%), ágar granulado (0,5\%) e 1,0 $\mathrm{mg} \mathrm{L}^{-1}$ de AIB (ácido indolbutírico), com pH ajustado para 5,8.

$\mathrm{Na}$ confirmação de que as gemas regeneradas tratavam de gemas adventícias e não gemas pré-formadas, foi realizada a análise histológica de uma fração do material regenerado.

Amostras dos tecidos in vitro foram coletadas e fixadas em FAA 50\% (formaldeído, ácido acético e etanol $50 \%$ ), pelo período de 24 horas. As amostras foram lavadas em álcool etílico 70\%, desidratadas em série alcoólica (álcool butílico) e embebidas em parafina, segundo Johansen (1940). Seções de $10 \mu \mathrm{m}$ de espessura foram coradas em combinação fuccina básica e azulde-astra e montadas em bálsamo-do-canadá.

\section{Resultados e Discussão}

O clone 1 foi o que apresentou os melhores resultados em relação ao calejamento, seguido pelos clones 2 e 3 (Figura 1). Apenas no clone 1 foi observado calejamento na classe de intensidade 3 , em três dos quatro tratamentos, utilizando-se os reguladores de crescimento TDZ e ANA. A eficiência do TDZ na produção de calos e posterior regeneração de gemas adventícias foi citada por Wilhelm (1999), quando concentrações mais altas dessa citocinina proporcionaram a produção de calos mais volumosos. Segundo Kaneda et al. (1997), melhor performance do TDZ, aparentemente, pode estar relacionada a maior atividade citocinínica ou a forma de ação diferente de outras citocininas durante o processo de desdiferenciação e rediferenciação celular, como também ao fato de o TDZ induzir a acumulação 
de auxinas e citocininas endógenas no tecido (Murthy et al., 1995).

Em relação ao clone 1, os resultados dos tratamentos com TDZ e ANA, com exceção do T3, que apresentava menores concentrações de TDZ, foram superiores aos dos tratamentos com BAP e ANA. Esses resultados corroboram os de Vieitez \& San-José (1996) que, utilizando como fonte de explante folhas de clones micropropagados de Fagus sylvatica, observaram que a formação de calos nos clones ocorria com maior in- tensidade nos meios de cultura com TDZ em relação aos que utilizaram o BAP. A melhor performance do TDZ em relação a outros reguladores de crescimento na proliferação de tecido calogênico também é citada por Murthy et al. (1998).

O clone 2 apresentou intensidade de calejamento na classe $1 \mathrm{em}$ todos os tratamentos envolvendo as duas citocininas, contudo calos na classe de intensidade 2 somente foram observados nos tratamentos com TDZ e ANA (tratamentos T1, T2 e T4).

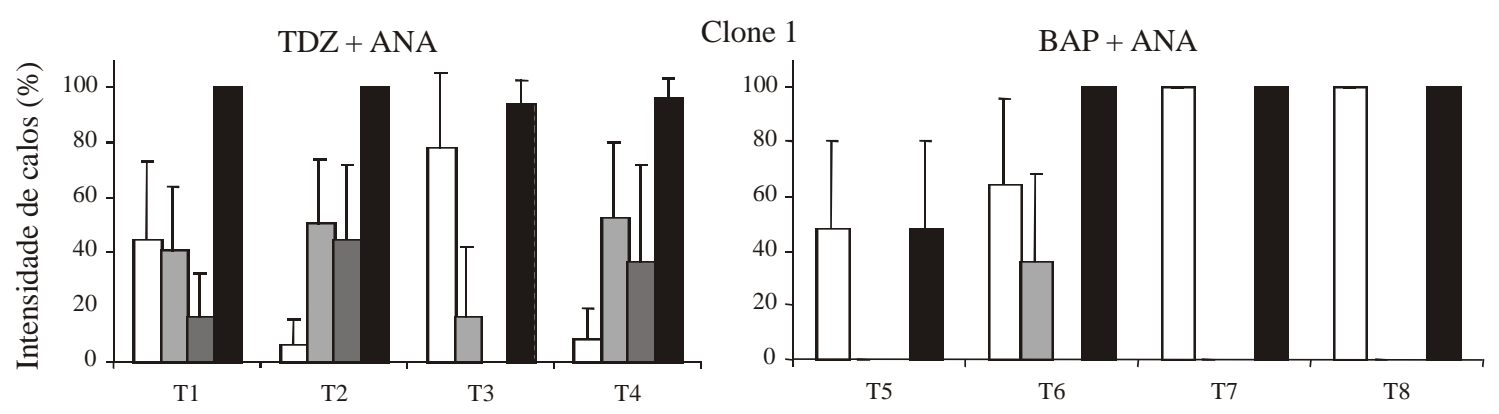

Clone 2
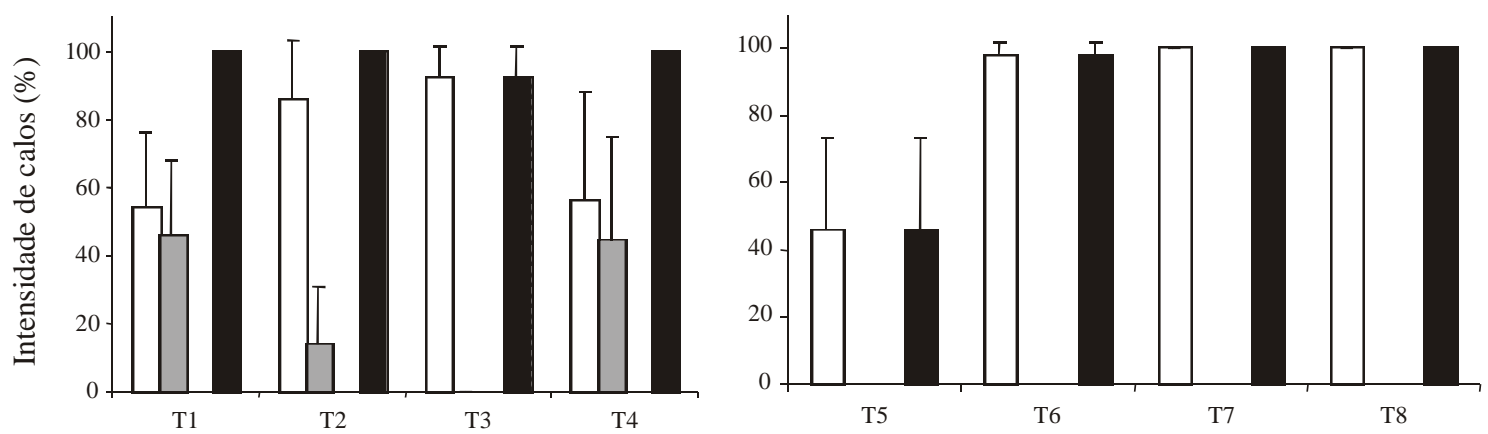

Clone 3
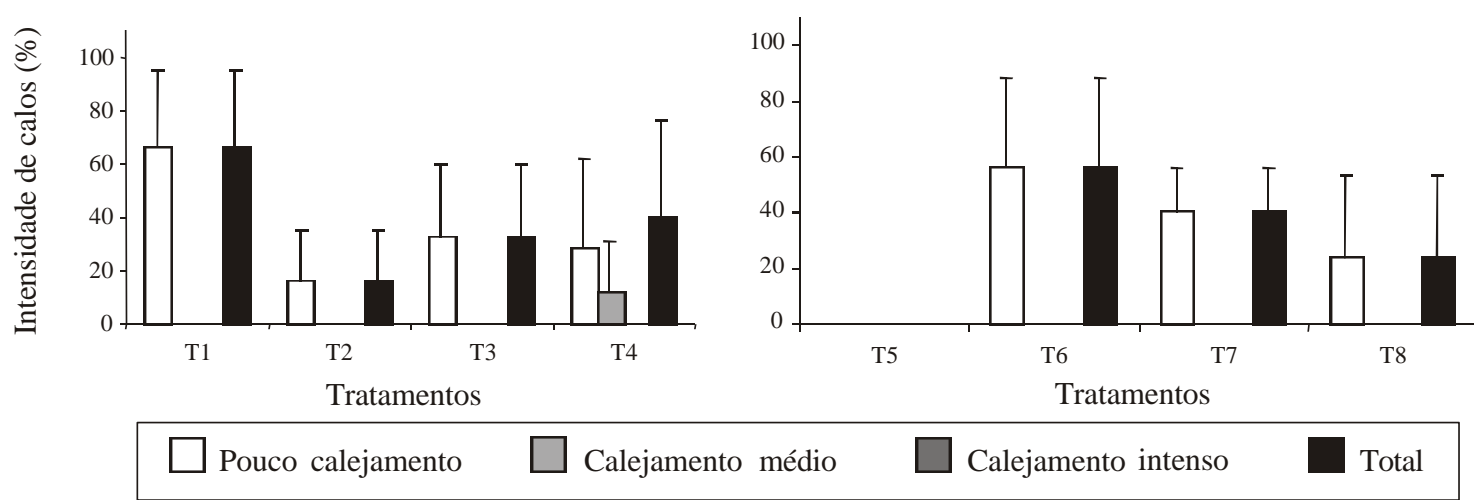

Figura 1. Intensidade de calogênese a partir de explante foliar provenientes de TDZ, BAP e ANA exógenos, avaliada em três clones de Eucalyptus grandis x E. urophylla. Tratamentos de 1 a 4, combinações de TDZ e ANA, em mg L-1 (T1: 0,5+0,5; T2: 0,5+0,1; T3: 0,05+0,01; T4: 1,0+0,1). Tratamentos de 5 a 8, combinações de BAP e ANA em mg L-1 (T5: 0,1+0,1; T6: 0,5+0,5; T7: 1,0+3,0; T8: 1,0+1,0). Barras verticais representam os desvios das médias. 
O clone 3, apesar de apresentar melhor resultado no tratamento T1 com TDZ e ANA, não demonstrou, de forma geral, desempenho superior nos tratamentos utilizando TDZ, em comparação com os tratamentos com BAP, como ocorreu nos clones 1 e 2 .

Nos três clones, os melhores resultados foram constatados nos tratamentos com os reguladores de crescimento TDZ e ANA (tratamentos T2, T4 e T1, para os clones 1,2 e 3, respectivamente). A vantagem da utilização dos reguladores de crescimento TDZ e ANA foi citada por Lu (1993), cujos estudos indicaram que o TDZ apresenta maior eficiência na presença de ANA. Contudo, esse autor citou que longas exposições ao TDZ não são recomendadas, pois podem causar hiper-hidricidade, crescimento anormal de gemas e dificuldade no enraizamento.

Diante desses resultados em relação à intensidade de calejamento, o clone 1 foi o que melhor respondeu quando cultivado em meio com $0,5 \mathrm{mg} \mathrm{L}^{-1}$ de TDZ e $0,1 \mathrm{mg} \mathrm{L}^{-1}$ de ANA (T2), indicando a maior eficiência do TDZ na obtenção de calos visando à organogênese desse clone em explante foliar.

No clone 1, os calos formados em explante foliar nos oito tratamentos com reguladores de crescimento foram classificados como compactos e semicompactos, em que as maiores concentrações de TDZ (tratamentos $\mathrm{T} 1, \mathrm{~T} 2$ e T4) proporcionaram calos compactos (Figura 2), sendo os calos compactos de coloração mais clara que os semicompactos. Nos tratamentos com BAP, foi observada a coloração bege-clara (T6), branca mesclada com bege (T7 e T8) e bege-escura (T5). Embora o tipo e concentração do regulador de crescimento utilizado tenha desempenhado importante papel na formação e textura de calos, os níveis de sacarose utilizados no meio de cultura podem afetar a textura dos mesmos, como citados por Cheng et al. (1992), quando concentrações intermediárias de sacarose (4\% a $6 \%$ ) proporcionaram calos mais friáveis na base de explantes de Eucalyptus sideroxylon, enquanto altas concentrações $(8 \%$ a $10 \%)$ inibiram a formação de calos.

No clone 2, todos os calos formados em explante foliar nos oito tratamentos com reguladores de crescimento foram classificados como compactos. Calos formados nos tratamentos com TDZ apresentavam a coloração branca mesclada com bege e bege-escuro, em proporções semelhantes nos tratamentos T1, T2 e T4, e somente calos bege-escuros no tratamento T3. Em calos formados nos tratamentos com BAP, observou-se a predominância da coloração bege-escura em T5, T6 e T8 e da bege-clara em $\mathrm{T} 7$.
No clone 3, foi observada nos tratamentos T1, T3 e T4, utilizando TDZ, formação de calo com aspecto polvilhado e solto na superfície do explante, classificados como semicompactos e semifriáveis. Todos os calos nesses tratamentos apresentavam, predominantemente, a coloração branca. Os tratamentos com BAP apresentaram somente calos compactos de coloração begeescura. Essa variedade de características observadas referentes à intensidade de formação e diferentes colorações e texturas dos calos foi citada por Warrag et al. (1991) e Hervé et al. (2001), como sendo resultado da influência de diferentes concentrações de reguladores de crescimento.

Com base nos resultados obtidos, foram escolhidos os tratamentos T2 $\left(0,5 \mathrm{mg} \mathrm{L}^{-1}\right.$ de TDZ e $0,1 \mathrm{mg} \mathrm{L}^{-1}$ de ANA) para o clone 1 , T4 $\left(1,0 \mathrm{mg} \mathrm{L}^{-1} \mathrm{de} \mathrm{TDZ}+0,1 \mathrm{mg} \mathrm{L}^{-1}\right.$ de ANA) para o clone 2 e T1 $\left(0,5 \mathrm{mg} \mathrm{L}^{-1}\right.$ de TDZ + $0,5 \mathrm{mg} \mathrm{L}^{-1}$ de ANA) para o clone 3 .

Os clones 1 e 3 apresentaram capacidade organogênica a partir de calos formados de explante foliar, indicando o potencial morfogênico desses materiais genéticos (Figura 3). O clone 2 não apresentou regeneração de gemas.

Nos três clones, houve mudanças quanto à coloração e textura dos calos durante a fase de regeneração em condições de luminosidade (Figura 4A). Houve maior compactação na superfície dos calos e aumento significativo da estrutura nodular formada na região do pecíolo (Figura 4B).

No clone 1, somente no tratamento T5 não foi observada regeneração de gemas, e o melhor resultado foi alcançado na concentração de $1,0 \mathrm{mg} \mathrm{L}^{-1}$ de BAP (T4). Nesse clone, todas as gemas regeneradas nos tratamentos com BAP ou BAP e ANA se originaram na região do pecíolo formado por um calo de aspecto nodular, sempre associadas à presença de antocianina. Hervé et al. (2001) também observaram a correlação entre protuberâncias densamente coesas e a regeneração por organogênese em explante foliar de Eucalyptus gunnii. Segundo esses autores, esses nódulos se formavam na parte proximal ao pecíolo e, após serem excisados e transferidos para meio de regeneração, desenvolviamse em gemas. Constataram, também, que os tecidos eram incapazes de regenerar gemas quando a parte proximal ao pecíolo da folha era removida.

A relação entre a presença de antocianina e a de organogênese foi relatada por Muralidharan \& Mascarenhas (1987) que, em explante foliar de E. camaldulensis, verificaram que os calos formados 
desenvolviam antocianina e, após quatro semanas de cultivo, gemas iniciais se desenvolviam nessas áreas de pigmentação. Subbaiah \& Minocha (1990), em trabalho com folhas e caule de E. tereticornis, constataram que os calos sempre se tornavam avermelhados antes do aparecimento dos primórdios de gemas. Também, Cuenca et al. (2000), na micropropagação por organogênese de Fagus sylvatica e F. orientalis, re- lataram que, nos calos formados, os locais de diferenciação de gemas eram aqueles que apresentavam antocianina.

O clone 3 apresentou, na região do calo formado por tecido nodular, gemas em estágio inicial de desenvolvimento, com a ressalva de que, na maioria dos casos, estavam associadas à presença de antocianina. Contudo, essas gemas não se desenvolveram quando subcultivadas em novo meio de regeneração ou alongamento.
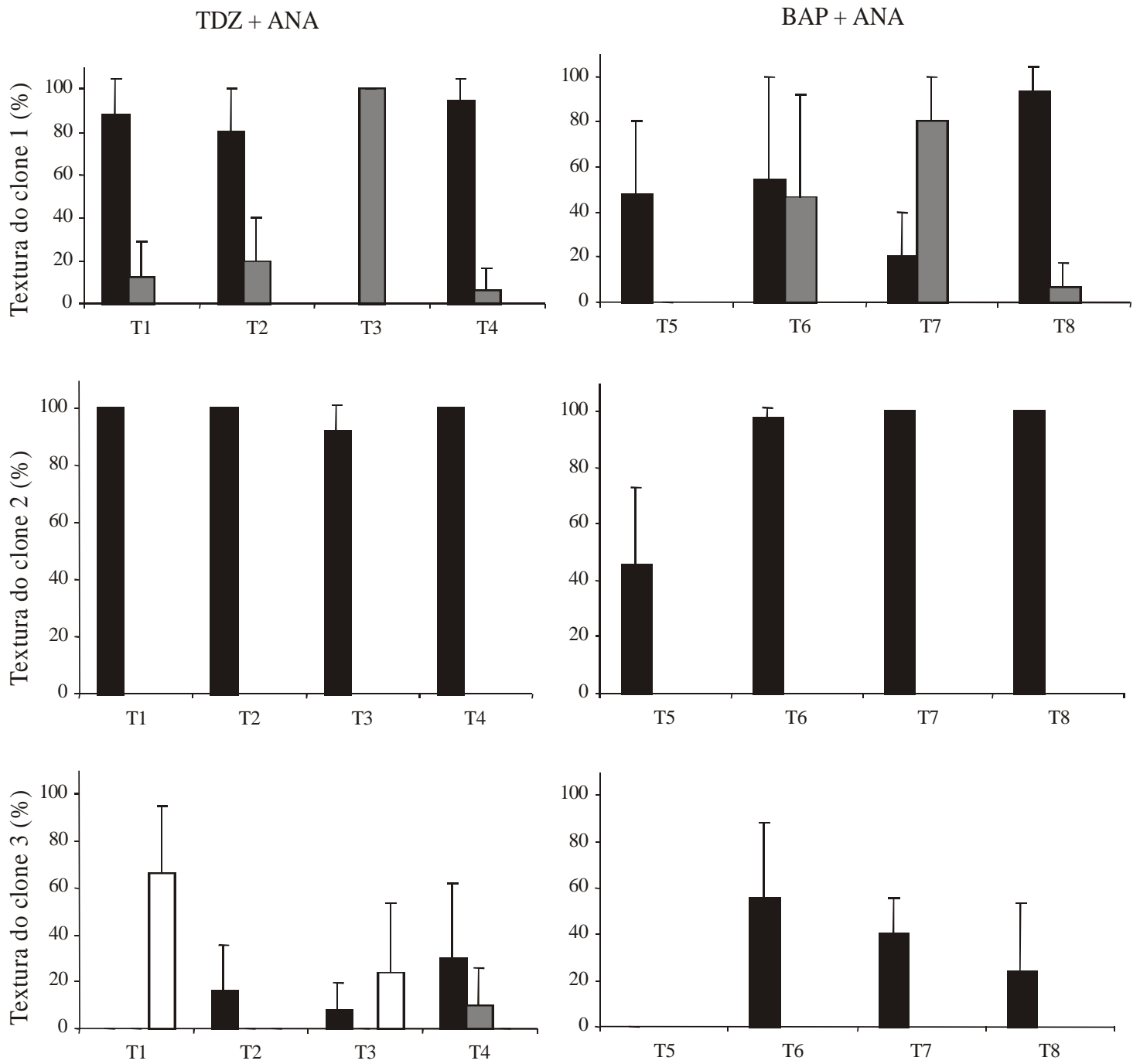

Tratamentos

Tratamentos

Compacto

Semicompacto

Semifriável

Figura 2. Textura observada em calos obtidos a partir de explante foliar, provenientes de TDZ, BAP e ANA exógenos, avaliada em três clones de Eucalyptus grandis x E. urophylla. Tratamentos de 1 a 4, combinações de TDZe ANA, em mg L-1 (T1: 0,5+0,5; T2: 0,5+0,1; T3: 0,05+0,01; T4: 1,0+0,1). Tratamentos de 5 a 8, combinações de BAP e ANA em mg L-1 (T5: 0,1+0,1; T6: 0,5+0,5; T7: 1,0+3,0; T8: 1,0+1,0). Barras verticais representam os desvios das médias. 

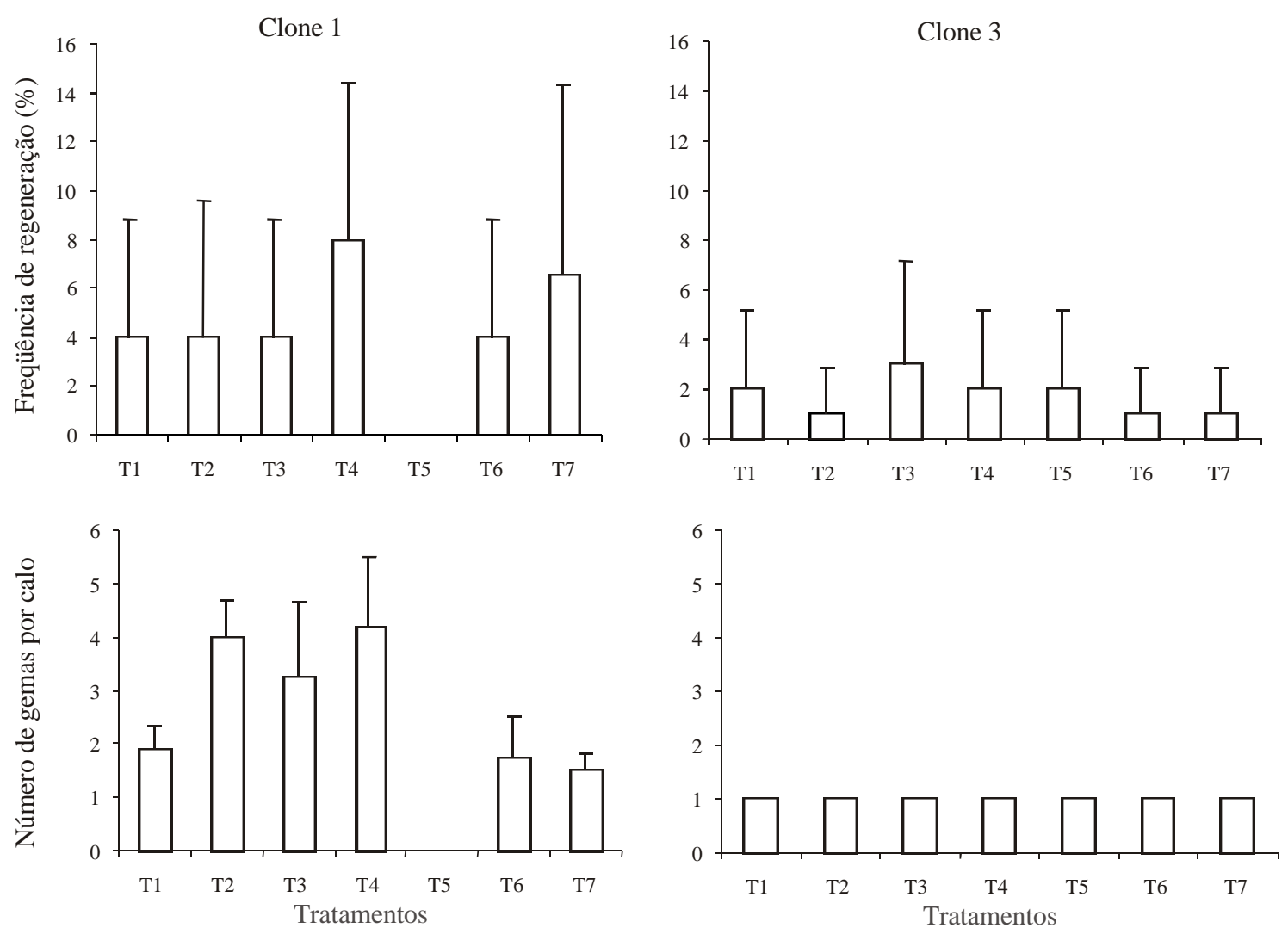

Figura 3. Porcentual dos calos que regeneraram gemas e número médio de gemas por calo provenientes de BAP e ANA exógenos avaliado nos clones 1 e 3 . Tratamentos de 1 a 7 , combinações de BAP e ANA, em mg L L $^{-1}$ (T1: 0,2+0,2; T2: 0,3+0,0; T3: 0,5+0,2; T4: 1,0+0,0; T5: 1,0+3,0; T6: 3,0+0,0; T7: 0,1+0,05). Barras verticais indicam os desvios das médias.
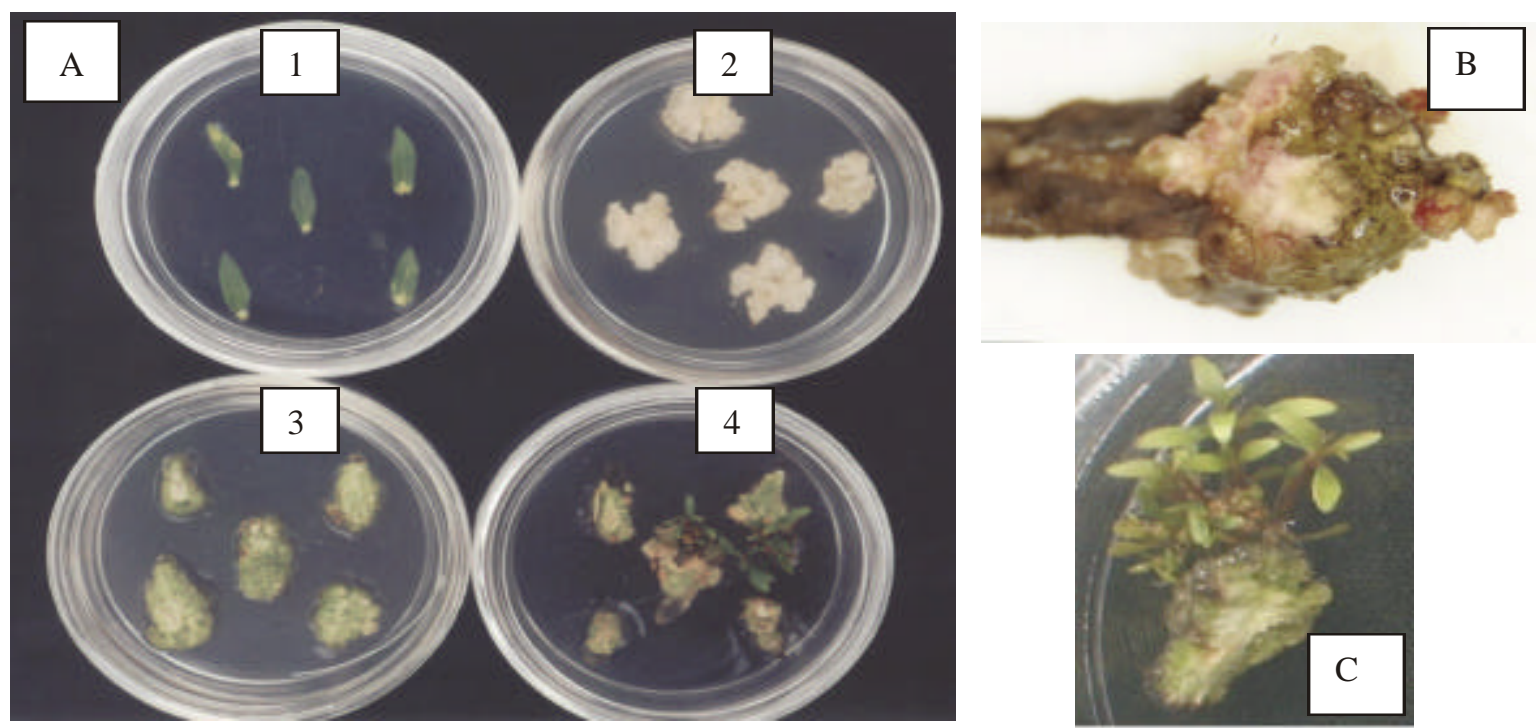

Figura 4. (A) Organogênse de explante foliar nas fases inicial (1), de calejamento no escuro (2), na presença de luz (3) e de regeneração de gemas adventícias (4) do clone 1 após 35 dias. (B) Detalhe da estrutura nodular desenvolvida na região do pecíolo nas condições de regeneração das gemas adventícias. (C) Detalhe da regeneração do explante foliar desenvolvida na região do pecíolo. 
Diante desses resultados, com relação à capacidade organogênica a partir de explante foliar dos clones em estudo, os clones 1 e 3 responderam quando cultivados em meio de regeneração, e no clone 1 o melhor resultado foi obtido com $1,0 \mathrm{mg} \mathrm{L}^{-1}$ de BAP, em que $8 \%$ dos calos formados a partir de explantes foliares regeneraram gemas, com número médio das formadas por calo igual a 4,2. No clone 3, o melhor resultado foi obtido com $0,5 \mathrm{mg} \mathrm{L}^{-1}$ de BAP e $0,2 \mathrm{mg} \mathrm{L}^{-1}$ de ANA, com número médio de gemas formadas por calo igual a um. Em relação ao porcentual de calos com regeneração de gemas, os valores obtidos foram inferiores aos de Subbaiah \& Minocha (1990), Tibok et al. (1995), Azmi et al. (1997) e Bandyopadhyay et al. (1999), que utilizaram como fonte de explante material juvenil. Em relação a trabalhos em que explantes foliares foram obtidos de clones de Eucalyptus, os resultados foram inferiores aos de Lainé \& David (1994), que obtiveram 38,5\% de calos regenerando gemas, porém próximo dos de Hervé et al. (2001), que obtiveram $8,8 \%$ de calos regenerando gemas com o número médio de gemas formadas por calo igual a quatro.

Os regenerantes obtidos foram transferidos para meio de cultura, na busca do desenvolvimento das gemas adventícias visando ao posterior enraizamento. Entretanto, dada a baixa taxa de regeneração, poucas gemas foram subcultivadas em meio específico, e a quantidade de gemas alongadas foi insuficiente para avaliar o potencial de enraizamento dos clones analisados.

As análises histológicas realizadas no explante foliar, revelaram a origem adventícia das gemas formadas. Após 35 dias do início de cultivo para explante foliar em meio de regeneração, houve a diferenciação das gemas e primórdios foliares a partir da região proximal das folhas. Em toda a lâmina foliar, houve a tendência de formação de maior ou menor índice de calejamento, de modo especial a partir de células do mesofilo junto à epiderme abaxial, permanecendo em alguns pontos intacta a epiderme adaxial.

Nas regiões associadas aos feixes vasculares, houve intensa atividade de divisão celular culminando na formação, em maior ou menor grau, de calos. À medida que se aproximava da região proximal das folhas, houve tendência de formação de protuberâncias de aspecto nodular que culminaram, em alguns casos, na formação de gemas adventícias (Figura 5A). Em ambos os clones, observou-se, na extremidade distal dos explantes, a diferenciação de gemas e primórdios foliares, seguindo o padrão típico de organogênese e apresentando a conti-
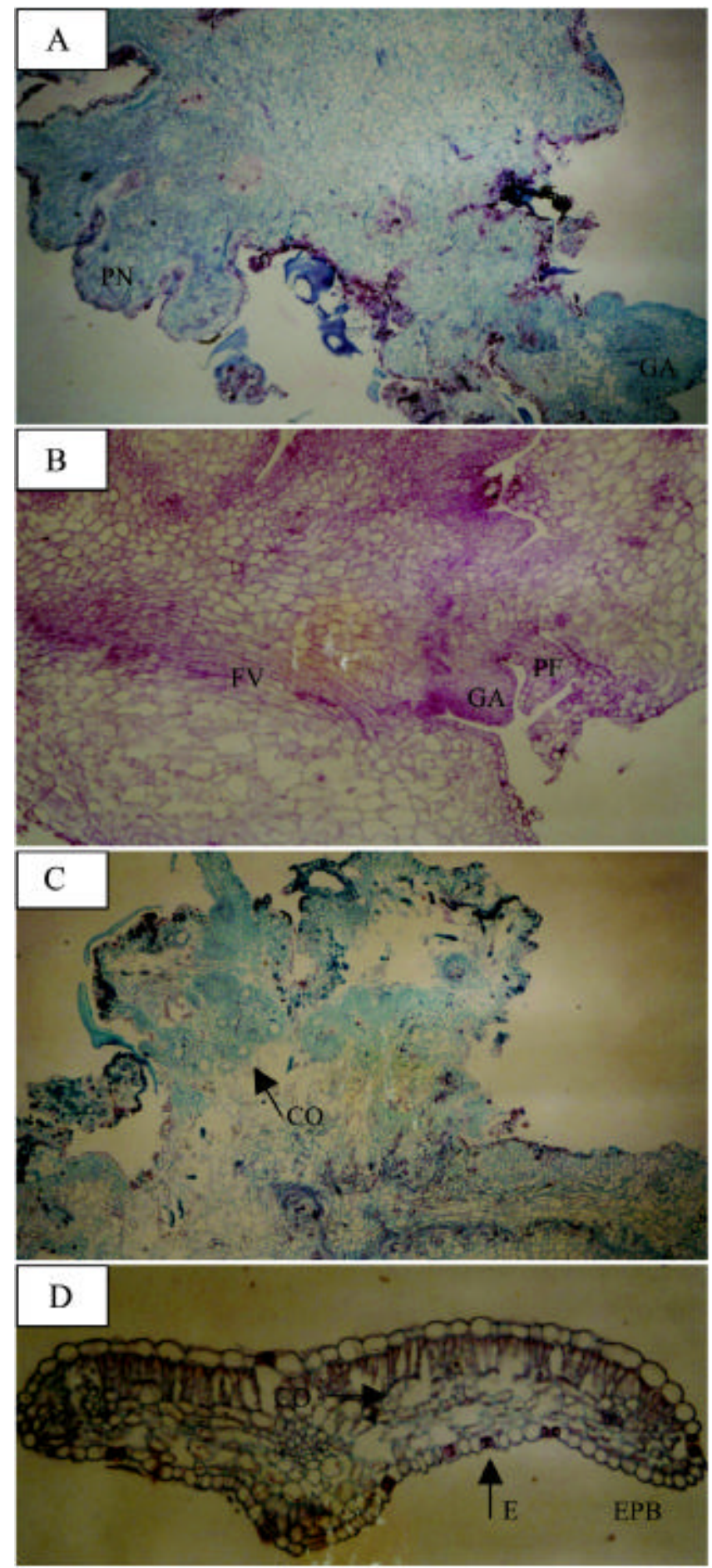

Figura 5. Fotomicrografias de cortes transversais (A e D) e longitudinais (B e C) de explantes foliares. (A) Formação de protuberâncias de aspecto nodular (PN) e gemas adventícias (GA) na região proximal do explante foliar. (B) Continuidade dos feixes vasculares (FV) entre a região de formação do calo com gemas adventícias (GA) e primórdios foliares (PF). (C) Presença de cavidades secretoras de óleo (CO). (D) Folha de um regenerante apresentando estômatos (E) na epiderme abaxial (EPB). 
nuidade vascular com o tecido original (Figura 5B). Pode-se observar, ainda, a presença de cavidades secretoras de óleo típicas da espécie (Figura 5C).

Nos regenerantes (Figura 4A), as folhas em corte transversal apresentaram estrutura típica do gênero, sendo anfiestomáticas e apresentando mesofilo diferenciado, com cavidades secretoras (Figura 5D).

\section{Conclusões}

1. Os reguladores de crescimento TDZ e ANA proporcionam maiores índices de calejamento, e a sua concentração varia de acordo com o clone utilizado.

2. A intensidade de calejamento e a textura do calo são os parâmetros que devem ser usados na escolha de um tratamento objetivando a organogênese em Eucalyptus.

3. A regeneração de gemas utilizando como fonte de explantes folhas de clones micropropagados se originam na região do pecíolo.

\section{Referências}

AZMI, A.; NOIN, M.; LANDRÉ, P.; PROUTEAU, M.; BOUDET, A.M.; CHRIQUI, D. High frequency plant regeneration from Eucalyptus globulus Labill. hypocotyls: ontogenesis and ploidy level of the regenerants. Plant Cell, Tissue and Organ Culture, v.51, p.9-16, 1997.

BANDYOPADHYAY, S.; CANE, K.; RASMUSSEN, G.; HAMILL, J.D. Efficient plant regeneration from seedling of two commercially important temperate eucalypt species - Eucalyptus nitens and E. globulus. Plant Science, v.140, p.189-198, 1999.

BONGA, J.M.; VON ADERKAS, P. In vitro culture of trees. Dordrecht: Kluwer Academic, 1992. 236p.

CHEN, Z.Z.; TSAY, J.Y.; CHUNG, J.D. Callus culture of Eucalyptus grandis $\mathrm{x}$ urophylla and preliminary studies on organogênesis and Agrobacterium-mediated transformation. Taiwan Journal Forestry Science, v.11, p.43-52, 1996.

CHENG, B.; PETERSON, C.M.; MITCHELL, R.J. The role of sucrose, auxin and explant source on in vitro rooting of seedling explants of Eucalyptus sideroxylon. Plant Science, v.87, p.207214, 1992.

COENEN, C.; LOMAX, T.L. Auxin-cytokinin interactions in higher plants: old problems and new tools. Trends in Plant Science, v.2, p.351-356, 1997.

CUENCA, B.; BALLESTER, A.; VIEITEZ, A.M. In vitro adventitious bud regeneration from internode segments of beech. Plant Cell, Tissue and Organ Culture, v.60, p.213-220, 2000.

GEORGE, E.F. Plant propagation by tissue culture: the technology. $2^{\text {nd }}$ ed. London: Exegetics, 1993. v.1.

HERVÉ, P.; JAUNEAU, A.; PÂQUES, M.; MARIEN, J.N.; BOUDET, A.M.; TEULIÈRES, C. A procedure for shoot organo- genesis in vitro from leaves and nodes of an elite Eucalyptus gunnii clone: comparative histology. Plant Science, v.161, p.645-653, 2001.

HO, C.K.; CHANG, S.H.; TSAY, J.Y.; TSAI, C.J.; CHIANG, V.L.; CHEN, Z.Z. Agrobacterium tumefaciens-mediated transformation of Eucalyptus camaldulensis and production of transgenic plants. Plant Cell Reports, v.17, p.675-680, 1998.

JOHANSEN, D.A. Plant microtechnique. New York: McGrawHill, 1940. 523p.

JOY IV, R.W.; THORPE, T.A. Shoot morphogenesis: structure, physiology, biochemistry and molecular biology. In: SOH, W.Y.; BHOJWANI, S.S. (Ed.). Morphogenesis in plant tissue cultures. London: Kluwer Academic, 1999. p.171-214.

KANEDA, Y.; TABEI, Y.; NISHIMURA, S.; HARADA, K.; AKIHAMA, T.; KITAMURA, K. Combination of thidiazuron and basal media with low salt concentrations increases the frequency of shoot organogenesis in soybeans [Glycine $\max$ (L.) Merr.]. Plant Cell Reports, v.17, p.8-12, 1997.

KITAHARA, E.H.; CALDAS, L.S. Shoot and root formation in hypocotyl callus cultures of Eucalyptus. Forest Science, v.21, p.242-243, 1975.

LAINÉ, E.; DAVID, A. Regeneration of plants from leaf explants of micropropagated clonal Eucalyptus grandis. Plant Cell Reports, v.13, p.473-476, 1994.

LU, C.Y. The use of thidiazuron in tissue culture. In Vitro Cellular and Development Biology - Plant, v.29, p.92-96, 1993.

MULLINS, K.V.; LLEWELLYN, D.J.; HARTNEY, V.J.; STRAUSS, S.; DENNIS, E.S. Regeneration and transformation of Eucalyptus camaldulensis. Plant Cell Reports, v.16, p.787-791, 1997.

MURALIDHARAN, E.M.; MASCARENHAS, A.F. In vitro plantlet formation by organogenesis in Eucalyptus camaldulensis and by somatic embryogenesis in Eucalyptus citriodora. Plant Cell Reports, v.6, p.256-259, 1987.

MURASHIGE, T.; SKOOG, F. A revised medium for rapid growth with tobacco tissue cultures. Physiologia Plantarum, v.15, p.473497, 1962.

MURTHY, B.N.S.; MURCH, S.J.; SAXENA, P.K. Thidiazuron: a potent regulator of in vitro plant morphogenesis. In Vitro Cellular and Development Biology - Plant, v.34, p.267-275, 1998.

MURTHY, B.N.S.; MURCH, S.J.; SAXENA, P.K. Thidiazuroninduced somatic embryogenesis in intact seedlings of peanut (Arachis hypogaea): endogenous growth regulator levels and significance of cotyledons. Physiologia Plantarum, v.94, p.268-276, 1995.

PIERIK, R.L.M. In vitro culture of higher plants. $4^{\text {th }}$ ed. Dordrecht: Kluwer Academic, 1997. 348p.

SERRANO, L.; ROCHANGE, F.; SEMBLAT, J.P.; MARQUE, C.; TEULIÈRES, C.; BOUDET, A.M. Genetic transformation of Eucalyptus globulus through biolistics: complementary development of procedures for organogenesis from zygotic embryos and stable transformation of corresponding proliferating tissue. Journal of Experimental Botany, v.47, p.285-290, 1996.

SUBBAIAH, M.M.; MINOCHA, S.C. Shoot regeneration from stem and leaf callus of Eucalyptus tereticornis. Plant Cell Reports, v.9, p.370-373, 1990. 
SUGIYAMA, M. Organogenesis in vitro. Current Opinion in Plant Biology, v.2, p.61-64, 1999.

TIBOK, A.; BLACKHALL, N.W.; POWER, J.B.; DAVEY, M.R. Optimized plant regeneration from callus derived from seedling hypocotyls of Eucalyptus urophylla. Plant Science, v.110, p.139$145,1995$.

VIEITEZ, A.M.; SAN-JOSÉ, M.C. Adventitious shoot regeneration from Fagus sylvatica leaf explants in vitro. In Vitro Cellular Development and Biology - Plant, v.32, p.140-147, 1996.
WARRAG, E.; LESNEY, M.S.; ROCKWOOD, D.J. Nodule culture and regeneration of Eucalyptus grandis hybrids. Plant Cell Reports, v.9, p.586-589, 1991.

WHITE, P.R. Further evidence on the significance of glycine, pyridoxine and nicotinic acid in the nutrition of excised tomato roots. American Journal of Botany, v.30, p.33-36, 1943.

WILHELM, E. Micropropagation of juvenile sycamore maple via adventitious shoot formation by use of thidiazuron. Plant Cell, Tissue and Organ Culture, v.57, p.57-60, 1999.

Recebido em 23 de julho de 2003 e aprovado em 20 de fevereiro de 2004 